\title{
Development and Characterization of Pharmacokinetic Parameters of Fast-Dissolving Films Containing Levocetirizine
}

\author{
Dhagla R. Choudhary * ${ }^{1}$, Vishnu A. Patel ${ }^{2}$, Usmangani K. ChHalotiya ${ }^{1}$, \\ Harsha V. PATEL ${ }^{1}$, Aliasgar J. KUndAWALA ${ }^{1}$ \\ ${ }^{1}$ Indukaka Ipcowala College of Pharmacy, New V V Nagar, Anand, Gujarat - 388121, India. \\ ${ }^{2}$ A. R. College of Pharmacy, V V Nagar, Anand, Gujarat - 388120, India. \\ * Corresponding author. E-mail: dhaglaram@gmail.com (D. R. Choudhary)
}

Sci Pharm. 2012; 80: 779-787

doi:10.3797/scipharm.1205-15

Published: July $22^{\text {nd }} 2012$

Accepted: July $22^{\text {nd }} 2012$

Received: $\quad$ May $31^{\text {st }} 2012$

This article is available from: http://dx.doi.org/10.3797/scipharm.1205-15

(c) Choudhary et al.; licensee Österreichische Apotheker-Verlagsgesellschaft m. b. H., Vienna, Austria.

This is an Open Access article distributed under the terms of the Creative Commons Attribution License (http://creativecommons.org/licenses/by/3.0/), which permits unrestricted use, distribution, and reproduction in any medium, provided the original work is properly cited.

\begin{abstract}
A fast-dissolving film containing levocetirizine, a non-sedative antihistamine drug, was developed using pullulan, xanthan gum, propylene glycol, and tween 80 as the base materials. The drug content of the prepared films was within an acceptable limit as prescribed by the USP. The film exhibited excellent stability for four months when stored at $40^{\circ} \mathrm{C}$ and $75 \%$ humidity. In vitro dissolution studies suggested a rapid disintegration, in which most of levocetirizine (93.54 \pm $3.9 \%$ ) dissolved within 90 seconds after insertion into the medium. Subsequently, Sprague-Dawley rats were used to compare the pharmacokinetic properties of the film preparation administered to the oral cavity, to those with oral administration of the pure drug solution. The pharmacokinetic parameters were similar between the two groups in which $A \mathrm{CC}_{0-\mathrm{t}}(\mathrm{ng} \mathrm{h} / \mathrm{ml}), \mathrm{AUC}_{0-\infty}$ (ng $\mathrm{h} / \mathrm{ml}) \mathrm{C}_{\max }(\mathrm{ng} / \mathrm{ml}), \mathrm{T}_{\max }(\mathrm{min}), \mathrm{K}_{\mathrm{el}}\left(\mathrm{h}^{-1}\right)$, and $\mathrm{t}_{1 / 2}(\mathrm{~h})$ of the reference were $452.033 \pm 43.68,465.78 \pm 48.16,237.16 \pm 19.87,30,0.453 \pm 0.051$, and 1.536 \pm 0.118 , respectively, for the film formulation $447.233 \pm 46.24,458.22 \pm 46.74$, $233.32 \pm 17.19,30,0.464 \pm 0.060$, and $1.496 \pm 0.293$, respectively. These results suggest that the present levocetirizine containing fast-dissolving film is likely to become one of the choices to treat different allergic conditions.
\end{abstract}

\section{Keywords}

Fast dissolving film • Levocetirizine • In-vitro dissolution studies • Pharmacokinetics • Drug content 


\section{Introduction}

Some patients, particularly pediatric and geriatric patients, have difficulty in swallowing or chewing solid dosage forms. Many pediatric and geriatric patients are unwilling to take these solid preparations due to fear of choking [1]. The fast-dissolving film is a new drug delivery technique to provide medicine to such patients. Fast-dissolving films have acquired great importance in the pharmaceutical industry due to their unique properties and advantages [2,3]. They undergo disintegration in the salivary fluids of the oral cavity within a minute, where they release the active pharmaceutical ingredient. Their characteristic benefits in terms of patient compliance, rapid onset of action, increased bioavailability (by sometimes bypassing the first-pass effect), and good stability make these films popular as the dosage form of choice [4-6].

An allergy is a hypersensitive disorder of the immune system. Allergic reactions occur due to environmental substances known as allergens. An allergy is one of four forms of hypersensitivity and is called type I hypersensitivity. It is characterized by the excessive activation of certain white blood cells called mast cells and basophils by a type of antibody known as IgE, resulting in an extreme inflammatory response. Mild allergies like hay fever are highly prevalent in the human population and cause symptoms such as allergic conjunctivitis, itchiness, and runny nose. A variety of tests now exist to diagnose allergic conditions; these include testing the skin for responses to known allergens or analyzing the blood for the presence and levels of allergen-specific IgE. Treatments for allergies include allergen avoidance, use of antihistamines, steroids or other oral medications, immunotherapy to desensitize the response to the allergen, and targeted therapy [7-9].

Levocetirizine (LCZ) is a third-generation non-sedative antihistamine, which works by blocking histamine receptors. It does not prevent the actual release of histamine from mast cells, but prevents it binding to its receptors. LCZ prevents the release of other allergic chemicals produced in response to allergens and the increased blood supply to the area, and provides relief from the typical symptoms of hay fever [10].

Levocetirizine is bitter in taste. The bitterness of the drug was lessened by using hydroxyl propyl $\beta$-cyclodextrin complexes as reported by Mahesh in 2010 and Dinge in 2008 $[11,12]$.

Pullulan is a natural polysaccharide produced from starch by cultivating the black yeast, Aureobasidium pullulans. It is a white, tasteless, odourless, and water-soluble powder. Pullulan (PI-20 grade) is the deionised form of pullulan, having an average molecular weight of 200,000 daltons and possesses excellent film-forming properties [13, 14].

\section{Materials and Methods}

\section{Materials}

Levocetirizine dihydrochloride (LCZ) was obtained as a gift sample from Cipla Ltd., Ahmedabad, Gujarat, India. Neotame, hydroxyl propyl $\beta$-cyclodextrin (HPß-CD), and xanthan gum were provided by Alkem pharmaceutical Pvt Ltd. Mumbai, India. Pullulan gum was provided as a gift sample by Gengwal Chemicals, Mumbai, India. Propylene glycol (PG) and tween 80 were purchased from Sigma chemicals. 


\section{Preparation of fast-dissolving films}

The basic components of FDFs were LCZ : HPß-CD complex $(0.432 \% \mathrm{w} / \mathrm{v}, 1: 1 \mathrm{molar}$ ratio), pullulan $(2 \% \mathrm{w} / \mathrm{v})$, xanthan gum $(0.4 \% \mathrm{w} / \mathrm{v})$, propylene glycol $(0.2 \% \mathrm{w} / \mathrm{w})$, and tween $80(0.1 \% \mathrm{w} / \mathrm{w})$ in $25 \mathrm{ml}$ of water. All of these excipients were dissolved in water by using a magnetic stirrer to obtain a homogenous dispersion. Then it was allowed to be kept aside for $8 \mathrm{~h}$ to remove air bubbles, and then $25 \mathrm{ml}$ of the dispersion was cast onto a glass petridish (Borosil, Gujarat, India) having a surface area of $64 \mathrm{~cm}^{2}$ and a $1.3 \mathrm{~cm}$ wall height. The dispersion was dried in a hot air oven at $45-50{ }^{\circ} \mathrm{C}$. After drying, the films were removed with the help of a sharp blade and kept in a desiccator for $24 \mathrm{hrs}$ before cutting it into small pieces, having an area of $6 \mathrm{~cm}^{2}$ for each film. Films with air bubbles, cuts, or imperfections were excluded from further study. Selected films were subjected to different evaluation parameters [15, 12].

\section{Appearance, weight, tensile strength, disintegration time, and content uniformity}

The prepared films were evaluated for different parameters like: appearance, weight [15], tensile strength [16, 17], content uniformity [11], and disintegration time [18].

\section{In vitro dissolution studies}

An in vitro dissolution study was performed for selected films for three minutes in the USP paddle apparatus using a $\mathrm{pH} 6.4$ buffer solution. The dissolution medium was kept at $37 \pm$ $0.5^{\circ} \mathrm{C}$ and rotated at $500 \mathrm{rpm}$. The samples $(5 \mathrm{ml})$ were withdrawn after every $30 \mathrm{sec}$ interval and replaced with a fresh buffer ( $\mathrm{pH} \mathrm{6.4)} \mathrm{solution.} \mathrm{One} \mathrm{ml}$ of the sample was then taken and diluted up to $10 \mathrm{ml}$ in a volumetric flask. The samples were analyzed for the drug content using a UV spectrophotometer at $231 \mathrm{~nm}$. Dissolution was performed three times for each formulation to calculate the drug-release profile [12].

\section{Stability study}

Short-term stability studies were performed for optimized films, and were placed in plastic containers and exposed to $40 \pm 0.5{ }^{\circ} \mathrm{C}$ and $75 \pm 5 \% \mathrm{RH}$ (ICH guidelines) for a period of four months. Different film properties like physical appearance of the film, mechanical properties, and drug content were evaluated at intervals of one week [19].

\section{Determination of pharmacokinetic parameters}

In this study, Sprague-Dawley rats were used. Their mean weight was $264.66 \pm 8.96 \mathrm{~g}$ in the range of 250-275 $\mathrm{g}$. Animals were housed in a room maintained on a 12-h light/dark cycle at $23 \pm 2{ }^{\circ} \mathrm{C}$ with free access to food and water. The experimental procedures were approved by the Committee for the Care and Use of Laboratory Animals at the IICP (Protocol number: IICP/PH/12-2010/02). For the administration of sample (film) preparation, $50 \mu \mathrm{l}$ aliquot of distilled water was dropped into the rat oral cavity under light ether anesthesia, then two halves $(1 \mathrm{~cm} \times 0.5 \mathrm{~cm})$ of the film preparation were applied to the buccal cavity bilaterally. For oral administration, rats were given $1 \mathrm{mg} / \mathrm{kg}$ of the LCZ dose (equivalent to the body weight of rat) in solution containing $1 \mathrm{ml}$ water, under light ether anesthesia [20]. Blood specimens were taken (every $0.5 \mathrm{ml}$ ) in a centrifuge plastic capillary tube by the intraorbital route at $0 \mathrm{~min}, 30 \mathrm{~min}, 1 \mathrm{~h}, 2 \mathrm{~h}, 4 \mathrm{~h}, 6 \mathrm{~h}$, and $12 \mathrm{~h}$ after drug administration. Blood was subjected to centrifugation at $10,000 \mathrm{rpm}$ for $15 \mathrm{~min}$, then plasma was taken in a polyethylene tube and stored at $-20^{\circ} \mathrm{C}$ until its assay. The concentration of levocetirizine was determined by HPLC-UV at $230 \mathrm{~nm}$ [21]. The HPLC-UV 
system that was used consisted of a pump (Perkin Elmer, USA) with universal loop injector (Rheodyne) of injection capacity $20 \mu \mathrm{l}$. The detector consisted of a UV detector; the reversed-phase column that was used was $\mathrm{RP}_{-} \mathrm{C}_{18}(5 \mu \mathrm{m}$ size, $250 \mathrm{~mm} 4.6 \mathrm{~mm}$ i.d. $)$ at ambient temperature. The mobile phase was a mixture of Acetonitrile : Buffer $\left(\mathrm{KH}_{2} \mathrm{PO}_{4}, \mathrm{pH}\right.$ 5.5, $0.02 \mathrm{M}, \mathrm{pH}$ was adjusted with $\mathrm{NaOH}) 70: 30 \%$ v/v [22, 23].

\section{Pharmacokinetic parameters and statistical calculation}

Pharmacokinetic parameters were derived from the plasma concentration vs. time plot. The peak plasma concentration $\left(C_{\max }\right)$ and the time to attain peak concentration $\left(T_{\max }\right)$ were obtained from experimental points of the plot. The other pharmacokinetic parameters were determined by using Kinetica software (Version 5, Adept Scientific, UK). The data of the reference (oral solution of the pure drug) and sample (film) were compared and statistically evaluated by Student's t-test.

\section{Results and Discussion}

\section{Appearance, weight, tensile strength, disintegration time, and content uniformity}

Prepared films were opaque in appearance. The weight and tensile strength of the films were found to be $83 \pm 6.9 \mathrm{mg}$ and $6.18 \pm 1.45 \mathrm{~N} / \mathrm{mm}^{2}$, respectively. The drug content was found to be $96.4 \pm 4.5 \%$, and the results suggested that the drug content was within the prescribed limit (85-115\%) as specified by the USP. Films were disintegrated in $16 \pm 1.56$ sec.

\section{In vitro dissolution studies}

An in vitro dissolution study was performed for the films for three minutes in a USP paddle apparatus using a pH 6.4 buffer solution. The prepared films released their $93.54 \pm 3.9 \%$ of drug in 90 sec.

\section{Stability study}

A stability study of selected films at $40 \pm 2{ }^{\circ} \mathrm{C} / 75 \% \mathrm{RH} \pm 5 \% \mathrm{RH}$ was carried out for four months. The results are shown in Table 1 . The result of the stability study revealed that there was no significant difference in the drug content of the formulation. The formulations showed satisfactory tensile strength at $40{ }^{\circ} \mathrm{C}$ and $75 \% \mathrm{RH}$. The physical appearance did not change considerably. These finding suggest that films are stable at high temperatures.

Tab. 1. Evaluation of different parameters during stability studies

\begin{tabular}{|c|c|c|c|}
\hline \multirow{2}{*}{$\begin{array}{l}\text { Time } \\
\text { (Month) }\end{array}$} & \multicolumn{3}{|c|}{ Parameters } \\
\hline & Appearance & Tensile strength $\left(\mathrm{N} / \mathrm{mm}^{2}\right)$ & Drug content (\%) \\
\hline 1 & +++ & $6.11 \pm 1.65$ & $96.34 \pm 2.09$ \\
\hline 2 & +++ & $5.98 \pm 1.59$ & $96.62 \pm 1.69$ \\
\hline 3 & +++ & $5.85 \pm 1.66$ & $95.78 \pm 1.67$ \\
\hline 4 & ++ & $5.81 \pm 1.17$ & $94.74 \pm 1.92$ \\
\hline
\end{tabular}




\section{Determination of pharmacokinetic parameters for the reference (oral solution of the pure drug) and sample (film)}

\section{Validation of method}

The intra-assay and inter-assay precision were determined with a quality control sample spiked with three different concentrations of levocetirizine $(50,200$, and $400 \mathrm{ng} / \mathrm{ml})$ as shown in Table 2. The intra-assay CV for the three quality control samples ranged from 12 to $15 \%$ and the inter-assay CV ranged from 8 to $17 \%$, where the acceptable value is less than or equal to $20 \%$ for the CV as proposed by the FDA. High accuracy and precision were achieved by the external standard method of calibration, thus an internal standard was not required [24].

Tab. 2. Intra-assay and inter-assay variation for reference (oral solution of the pure drug) and sample (film); (mean $\pm S D, n=3$ ).

\begin{tabular}{lccccc}
\hline QC & Levocetirizine & \multicolumn{2}{c}{ Intra-Day } & \multicolumn{2}{c}{ Inter-Day } \\
\cline { 3 - 6 } sample & added (ng/mI) & $\begin{array}{c}\text { Area } \\
\text { (mean } \pm \text { SD) }\end{array}$ & CV (\%) & $\begin{array}{c}\text { Area } \\
\text { (mean } \pm \text { SD) }\end{array}$ & CV (\%) \\
\hline LQC & 50 & $15473 \pm 2471$ & 15.9 & $14233 \pm 2486$ & 17.4 \\
MQC & 200 & $54021 \pm 6704$ & 12.4 & $55660 \pm 4646$ & 8.3 \\
HQC & 400 & $91115 \pm 11939$ & 13.1 & $88248 \pm 8997$ & 10.1 \\
\hline QC = Quality Control; LQC = Low Quality Control; MQC=Medium Quality Control; & \\
HQC= High Quality Control; CV = Coefficient of variance. & & & \\
\hline
\end{tabular}

Comparison of concentrations of drug in plasma at different time intervals for the reference (oral solution of the pure drug) and sample (film).

As reported earlier, the HPLC determination of levocetirizine in human plasma was assayed by Macek in 1999 [24]. In our study, we have successively measured the concentration of levocetirizine dihydrochloride in rat plasma by using HPLC with UV detection. Table 3 and Figure 1show the time course of changes in levocetrizine concentrations in rat plasma, after oral administration of levocetirizine solution or administration of fast-dissolving film to the oral cavity. The pattern of changes in plasma concentrations was similar between the two groups, although the concentrations were slightly, but not significantly, higher in the oral solution-treated group.

Tab. 3. Plasma levels of levocetirizine in plasma for reference (oral solution of the pure drug) and sample (film); (mean \pm SD, $n=6$ ).

\begin{tabular}{lcc}
\hline \multirow{2}{*}{ Time (min) } & \multicolumn{2}{c}{ Levocetirizine content (ng/ml) } \\
\cline { 2 - 3 } & Oral solution (reference) & Film (sample) \\
\hline 0 & 0 & 0 \\
15 & $207 \pm 12$ & $205 \pm 9$ \\
30 & $237 \pm 19$ & $233 \pm 17$ \\
60 & $187 \pm 17$ & $184 \pm 12$ \\
120 & $101 \pm 9$ & $100 \pm 9$ \\
240 & $8 \pm 2$ & $7 \pm 2$ \\
360 & $6 \pm 2$ & $5 \pm 2$ \\
\hline
\end{tabular}


Since the film and solution remain in the oral cavity for a few seconds (5-10 sec), there are fewer chances of pre-gastric absorption, so that this study was carried out only on blood profiles.

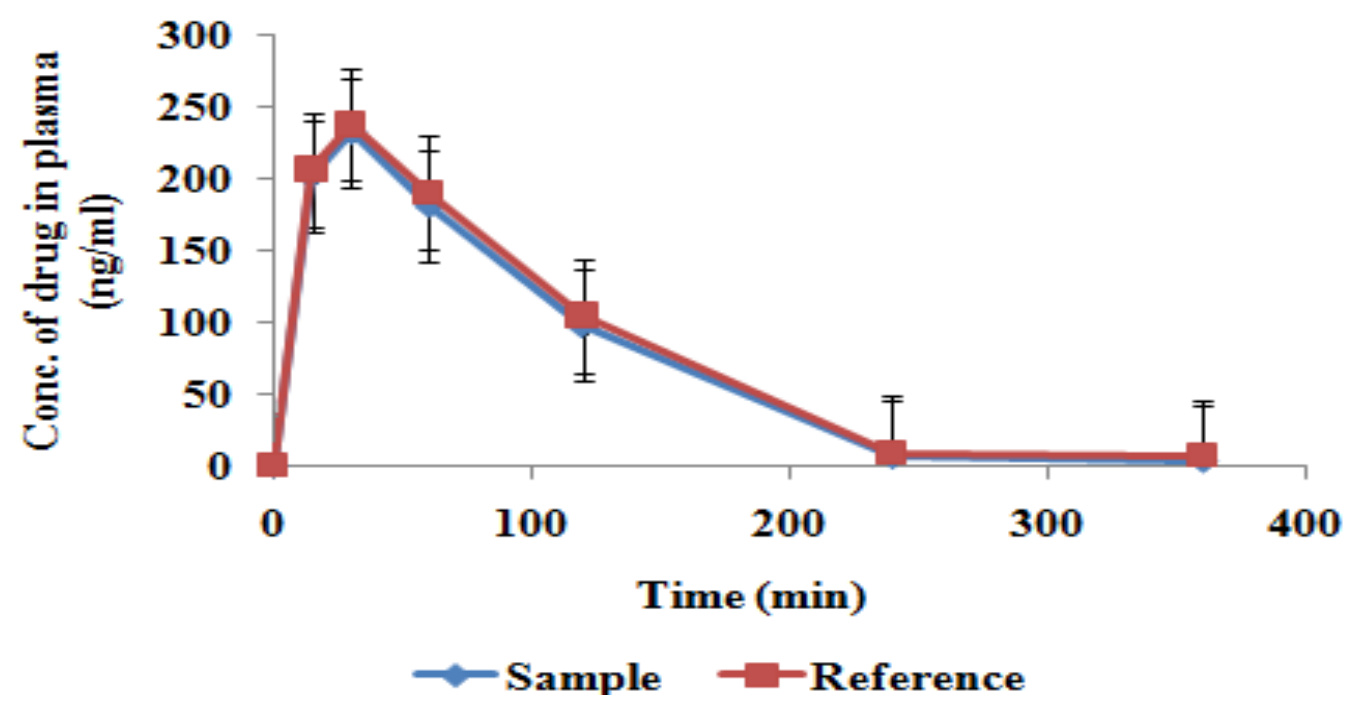

Fig. 1. Comparison of the concentration of levocetirizine in plasma for reference (oral solution of the pure drug, $n=6$ ) and sample (film); (mean $\pm S D, n=6$ ).

\section{Comparison of pharmacokinetic parameters of levocetirizine between reference (oral solution of the pure drug) and sample (film) in rats.}

The pharmacokinetic parameters were evaluated from the profiles of 12 rats (six rats each for the reference and sample). The pharmacokinetic parameters for the reference (oral solution of the pure drug) were found as follows: $A_{U C_{0-t}} 452.033 \pm 43.68 \mathrm{ng} \mathrm{h} / \mathrm{ml}, \mathrm{AUC}_{0-\infty}$ $465.78 \pm 48.16 \mathrm{ng} \mathrm{h} / \mathrm{ml}, \mathrm{C}_{\max } 237.16 \pm 19.87 \mathrm{ng} / \mathrm{ml}, \mathrm{T}_{\max } 30$ minutes, $\mathrm{K}_{\mathrm{el}} 0.453 \pm 0.0519$ $\mathrm{h}^{-1}$, and $\mathrm{t}_{1 / 2} 1.536 \pm 0.118 \mathrm{~h}$. The pharmacokinetic parameters for the sample (film) were found as follows- $A_{U C} U_{0-t} 447.233 \pm 46.24 \mathrm{ng} \mathrm{h} / \mathrm{ml}, A_{U} C_{0_{-\infty}} 458.22 \pm 46.74 \mathrm{ng} \mathrm{h} / \mathrm{ml}, C_{\max }$ $233.32 \pm 17.198 \mathrm{ng} / \mathrm{ml}, \mathrm{T}_{\max } 30$ minutes, $\mathrm{K}_{\mathrm{el}} 0.464 \pm 0.0601 \mathrm{~h}^{-1}$, and $\mathrm{t}_{1 / 2} 1.496 \pm 0.293 \mathrm{~h}$ (Table 4).

Tab. 4. Comparison of pharmacokinetic parameters of levocetirizine between the sample (film) and reference (oral solution of the pure drug) in Sprague-Dawley rats (mean $\pm S D, n=6$ ).

\begin{tabular}{lcc}
\hline Parameters & Reference (Oral solution) & Sample (Film) \\
\hline $\mathrm{AUC}_{0-\mathrm{t}}(\mathrm{ng} . \mathrm{h} / \mathrm{ml})$ & $452.033 \pm 43.68$ & $447.233 \pm 46.24$ \\
$\mathrm{AUC}_{0-\infty}(\mathrm{ng} . \mathrm{h} / \mathrm{ml})$ & $465.78 \pm 48.16$ & $458.22 \pm 46.74$ \\
$\mathrm{C}_{\max }(\mathrm{ng} / \mathrm{ml})$ & $237.16 \pm 19.87$ & $233.32 \pm 17.19$ \\
$\mathrm{~T}_{\max }(\mathrm{minute})$ & 30 & 30 \\
$\mathrm{~K}_{\mathrm{el}}\left(\mathrm{h}^{-1}\right)$ & $0.453 \pm 0.519$ & $0.464 \pm 0.601$ \\
$\mathrm{t}_{1 / 2}(\mathrm{~h})$ & $1.536 \pm 0.118$ & $1.496 \pm 0.293$ \\
\hline
\end{tabular}


The Analysis of Variance (ANOVA) for data from $A \cup C_{0-t}, A \cup C_{0-\infty}, C_{\max }$, and $T_{\max }$ showed no statistically significant difference between the two formulations. This suggests that both of the formulations have similar blood profiles. The respective $95 \% \mathrm{Cl}$ of the ondansetron sample/reference percent ratios were 98.93\% (91.14-118.36\%) for $\mathrm{AUC}_{0-\mathrm{t},}, 97.39 \%$ (92.34-115.61) for $\mathrm{AUC}_{0-\infty}$, and 98.38\% (89.34-114.41\%) for $\mathrm{C}_{\max }$, while the acceptable range was $80-125 \%$ for $A \cup C_{0-t}$ and $A \cup C_{0-\infty}$, and $70-143 \%$ for $C$ max as proposed by the FDA and the ANVISA (Table 5).

Tab. 5. Sample (film) to reference (oral solution of the pure drug) ratio of different pharmacokinetic parameters for levocetirizine (mean $\pm S D, n=6$ ).

\begin{tabular}{lccc}
\hline $\begin{array}{l}\text { Pharmacokinetic } \\
\text { parameters }\end{array}$ & $\begin{array}{c}\text { Sample } \\
\text { (Film) }\end{array}$ & $\begin{array}{c}\text { References } \\
\text { (Oral solution) }\end{array}$ & $\begin{array}{c}\text { Sample I } \\
\text { Reference ratio (\%) }\end{array}$ \\
\hline $\mathrm{AUC}_{0-\mathrm{t}}(\mathrm{ng} . \mathrm{h} / \mathrm{ml})$ & 447.233 & 452.033 & 98.93 \\
$\mathrm{AUC} \mathrm{C}_{0-\infty}(\mathrm{ng} . \mathrm{h} / \mathrm{ml})$ & 458.220 & 465.780 & 97.39 \\
$\mathrm{C}_{\max }(\mathrm{ng} / \mathrm{ml})$ & 233.32 & 237.16 & 98.38 \\
\hline
\end{tabular}

The results of this study showed that there was no significant difference in the blood profile of the reference (oral solution of the pure drug) and the sample (film) as shown in Table 4.

\section{Conclusion}

The prepared films of levocetirizine revealed excellent mechanical properties, drug content, and stability. The pattern of changes in plasma concentrations of the drug was similar between the two groups, although the concentrations were slightly, but not significantly, higher in the oral solution-treated group. No significant differences were observed in the pharmacokinetic parameters obtained from rats with the oral administration of levocetirizine solution of the pure drug and those with the film. Hence, the present fast-dissolving films containing levocetirizine are considered to be potentially useful for treating different allergic conditions.

Based on the results, it is concluded that FDFs are convenient and reliable dosage forms that can get rid of the common problems associated with solid dosage forms.

\section{Authors' Statements}

\section{Competing Interests}

The authors declare no conflict of interest.

\section{Animal Rights}

The institutional and (inter)national guide for the care and use of laboratory animals was followed. See the 'materials and methods' part for details. 


\section{References}

[1] Slowson M, Slowson S.

What to do when patients cannot swallow their medications.

Pharm Times. 1985; 51: 90-96.

[2] Liang AC, Chen LH.

Fast dissolving intraoral drug delivery systems.

Exp Opin Ther Patents. 2001; 11: 981-986.

http://dx.doi.org/10.1517/13543776.11.6.981

[3] Borsadia S, O'Halloran D, Osborne JL.

Quick dissolving films-A novel approach to drug delivery.

Drug Deliv Technol. 2003; 3: 63-66.

[4] Vondrak B, Barnhart S.

Dissolvable films for flexible product format in drug delivery.

Pharm Tech. 2008: Suppl: S20-S28.

[5] Vollmer U, Galfetti P.

Rapid film: Oral thin films as an innovative drug delivery system and dosage form.

Drug Dev Report. 2006; 64-67.

[6] Klancke J.

Dissolution testing of orally disintegrating tablets.

Dissolution Technol. 2003; 10: 6-8.

[7] Kay AB.

Overview of allergy and allergic diseases: with a view to the future.

Br Med Bull. 2000; 56: 843-864.

http://dx.doi.org/10.1258/0007142001903481

[8] Holgate ST.

Asthma and allergy--disorders of civilization?

QJM. 1998; 91: 171-184.http://dx.doi.org/10.1093/qjmed/91.3.171

[9] Rusznak C, Davies RJ.

$A B C$ of allergies. Diagnosing allergy.

BMJ. 1998; 316: 686-689.

http://dx.doi.org/10.1136/bmj.316.7132.686

[10] http://en.wikipedia.org (03/03/2012)

[11] Mahesh A, Shastri N, Sadanadam M.

Development of Taste Masked Fast Desintegrating Films of Lecocetirizine Dihydrochloride For Oral Use.

Current Drug Deliv. 2010; 7: 21-27.

http://dx.doi.org/10.2174/156720110790396454

[12] Dinge A, Nagarsenker M.

Formulation and evaluation of fast dissolving films for delivery of Triclosan to the oral cavity.

AAPS PharmSciTech. 2008; 9: 349-356.

http://dx.doi.org/10.1208/s12249-008-9047-7

[13] Rekha MR, Chandra PS.

Pullulan as a promising biomaterial for biomedical applications: A perspective.

Trends Biomater Artif Organs. 2007; 20: 1-6.

[14] Diab T, Biliaderis CG, Gerasopoulos D, Sfakiotakis E.

Physicochemical properties and application of pullulan edible films and coatings in fruit preservation. J Sci Food Agric. 2001; 81: 988-1000.

http://dx.doi.org/10.1002/jsfa.883 
[15] Mishra R, Amin A.

Formulation and characterization of rapidly dissolving films of cetirizine hydrochloride using pullulan as a film forming agent.

Indian J Pharm Educ Res. 2011; 45: 71-77.

[16] Brindle LP, Krochta JM.

Physical properties of whey protein-hydroxyl propyl methyl cellulose blend edible films.

J Food Sci. 2008; 73: 446-454.

http://dx.doi.org/10.1208/s12249-008-9047-7

[17] Felton LA, O'Donnell PB, McGinity JW.

Mechanical properties of polymeric films prepared from aqueous dispersions.

In: Aqueous polymeric coatings for pharmaceutical dosage forms.

New York, USA: Informa health. 2008; 176-178.

[18] Doaa AE, Nevine SA.

Formulation of a novel tianeptine sodium orodispersible film.

AAPS PharmSciTech. 2010; 11: 1018-1024.

http://dx.doi.org/10.1208/s12249-010-9464-2

[19] Mashru RC, Sutariya VB, Sankalia MG, Parikh PP.

Development and evaluation of fast dissolving film of salbutamol sulphate.

Drug Dev Ind Pharm. 2005; 1: 25-34.

http://www.ncbi.nlm.nih.gov/pubmed/15704855

[20] Gupta A, Gillard M, Christophe B, Chatelain P, Massingham R, Hammarlund-Udenaes M.

Peripheral and central $\mathrm{H}_{1}$ histamine receptor occupancy by levocetirizine, a non-sedating antihistamine; a time course study in the guinea pig.

Br J Pharmacol. 2007; 151: 1129-1136.

http://dx.doi.org/10.1038/sj.bjp.0707318

[21] Shimoda H, Taniguchi K, Nishimura M, Matsuura K, Tsukioka T, Yamashita H.

Preparation of a fast dissolving oral thin film containing dexamethasone: A possible application to antiemesis during cancer chemotherapy.

Eur J Pharm Biopharm. 2009; 73: 361-365.

http://dx.doi.org/10.1016/j.ejpb.2009.08.010

[22] Dedania Z, Dedania R, Karkhanis V, Sagar GV, Baldania M, Sheth NR.

RP-HPLC Method for Simultaneous Estimation of Omeprazole and Ondansetron in combined dosage forms.

Asian J Res Chem. 2009; 2: 108-111.

[23] Arayne, AS, Sultana N, Nawaz M.

Simultaneous quantification of cefpirome and cetirizine or levocetirizine in pharmaceutical formulations and human plasma by RP-HPLC.

J Anal Chem. 2008; 63: 881-887.

http://dx.doi.org/10.1134/S1061934808090153

[24] Macek J, Ptacek P, Kliıma J.

Determination of cetirizine in human plasma by high-performance liquid chromatography.

J Chromatogr B. 1999; 736: 231-235.

http://dx.doi.org/10.1016/S0378-4347(99)00464-8 